\title{
Redaksioneel
}

\section{Waarom moet Suid-Afrikaanse wetenskaplikes hulle eie nasionale tydskrifte steun?}

Die primêre doelstelling van wetenskaplike navorsingstydskrifte is om die internasionale gemeenskap van doeltreffende wetenskaplike kommunikasiemedia te voorsien.

By nasionale tydskrifte word die primêre doelstelling verder uitgebou, sodat 'n bepaalde land se wetenskaplikes hulle eie navorsingsresultate gesamentlik kan aanbied. Daardeur word 'n bydrae tot internasionale kommunikasie gelewer. Dit dien ook as 'n uitstalvenster vir die navorsing wat primêr in 'n bepaalde land gedoen word en die prestige van dié land word daardeur verhoog. Hoë kwaliteit van aanbieding is dus ' $n$ vereiste.

Binne ' $n$ bepaalde vakvereniging is ' $n$ eie navorsingstydskrif in die eerste plek 'n kommunikasiemedium vir sy lede. Dit is 'n diens wat aan die vereniging 'n sekere identiteit gee. Die kwaliteit van die tydkskrif kan die aansien van die vereniging en sy lede betekenisvol verhoog. Gevolglik streef die meeste verenigings na die uitgee van 'n eie navorsingstydskrif.

Die koste van so 'n onderneming is tans van so 'n aard dat min verenigings die finansiële las kan dra om 'n tydskrif van internasionale standaard uit te gee. Die gevolg is dat sy eie lede traag is om in sy eie tydskrif te publiseer.
Met die koms van nasionale tydskrifte is die redaksionele verantwoordelikheid nog steeds dié van die betrokke vakverenigings, terwyl die Buro vir Wetenskaplike Publikasies vir die tegniese versorging verantwoordelik is. Só kan die doelstellings van wetenskaplike publikasie wat die Republiek en die onderskeie vakverenigings betref, verwesenlik word.

Om hierdie ideaal te bereik sal Suid-Afrikaanse wetenskaplikes 'n verantwoordelikheidsin moet ontwikkel om in hulle eie nasionale navorsingstydskrifte, wat tegnies reeds van internasionale standaard is, te publiseer. Argumente dat artikels wat in SuidAfrikaanse tydskrifte gepubliseer word, nie gelees word nie, kan nie meer summier aanvaar word nie. Die Raad vir Wetenskaplike Publikasies het die beleid om nasionale tydskrifte aan sekere vakmanne, wat deur die onderskeie vakverenigings aangedui word, asook aan belangrike wêreldbiblioteke, gratis beskikbaar te stel. Verder moet daarop gelet word dat ekserptydskrifte die eksklusiwiteit van die groot lande se tydskrifte ongedaan maak.

Suid-Afrikaanse wetenskaplikes, $u$ het ' $n$ verantwoordelikheid teenoor die land om goeie navorsing te doen, maar ook om in u eie nasionale tydskrifte te publiseer!

A. Strasheim 